\title{
Peningkatan Prestasi Belajar Siswa pada Pelajaran Bahasa Indonesia Materi Menulis Teks Resensi dengan Menerapkan Model Pembelajaran Kooperatif Tipe Think Pair Share (TPS) di Kelas XI MIPA 1 SMAN 2 Bolo Semester II Tahun Pelajaran 2020/2021
}

\author{
Agustina \\ SMA Negeri 2 Bolo, Bima, Indonesia \\ *Coresponding Author: agustina.ss46@yahoo.com \\ Dikirim: 14-11-2021; Direvisi: 15-11-2021; Diterima: 16-11-2021
}

\begin{abstract}
Abstrak: Penelitian tindakan kelas ini bertujuan mendeskripsikan penerapan dan dampak model pembelajaran kooperatif tipe Think Pair Share (TPS) pada prestasi belajar siswa dalam mata pelajaran Bahasa Indonesia materi menulis teks resensi di kelas XI MIPA di SMAN 2 Bolo Semester II Tahun Pelajaran 2020/2021. Penelitian melibatkan 32 siswa, yang terdiri dari 15 orang laki-laki dan 17 orang perempuan. Hasil penelitian pra-siklus yang telah dilakukan peneliti, prestasi belajar siswa rendah, hal ini ditunjukkan dengan rendahnya ratarata nilai formatif tes siswa yakni rata-rata 70.00 dengan ketuntasan klasikal $72.00 \%$. Dengan kriteria keberhasilan yang ditentukan yakni rata-rata $\geq 73.00$ dengan ketuntasan klasikal $\geq 85.00 \%$, maka penelitian dilakukan dalam 2 siklus. Prestasi belajar siswa siklus I rata-rata 72.70 nilai rata-rata ini mengalami peningkatan sebelum diadakan perbaikan $(+2.70)$ dengan persentase ketuntasan $77.00 \%$, nilai persentase ini mengalami peningkatan dibanding sebelum diadakan perbaikan $(+5.00)$. Prestasi belajar siswa siklus II rata-rata 76.76 dimana nilai rata-rata ini mengalami peningkatan sebelum diadakan perbaikan $(+4.06)$ dengan persentase ketuntasan $88.80 \%$, dan nilai persentase ini mengalami peningkatan dibanding sebelum diadakan perbaikan $(+11.80)$. Peningkatkan prestasi belajar siswa, disebabkan oleh peningkatan aktivitas, interaksi guru dan siswa dalam proses pembelajaran di kelas dengan menerapkan model pembelajaran Kooperatif Tipe Think Pair Share (TPS) yang dilaksanakan sejalan dengan nilai kinerja guru. Dengan demikian, kriteria keberhasilan telah dicapai dengan sukses pada siklus II.
\end{abstract}

Kata Kunci: prestasi belajar; pembelajaran kooperatif tipe Think Pair Share (TPS)

Abstract: This classroom action research aimed to describe the application and impact of the Think Pair Share (TPS) cooperative learning model on student achievement in Indonesian subjects for writing review texts in class XI MIPA at SMAN 2 Bolo Semester II for the 2020/2021 academic year. The study involved 32 students, consisting of 15 boys and 17 girls. The results of pre-cycle research that has been carried out by researchers, student learning achievement was low, this was indicated by the low average formative test scores of students, namely an average of 70.00 with $72.00 \%$ classical completeness. As the success criteria determined, namely an average of 73.00 with classical completeness $85.00 \%$, the research was carried out in 2 cycles. Student learning achievement in cycle I averaged 72.70 this average value increased before the improvement was made $(+2.70)$ with a completeness percentage of $77.00 \%$, this percentage value increased compared to before the improvement was held (+5.00). The average student learning achievement in cycle II was 76.76, in which this average value has increased before the improvement was made $(+4.06)$ with a completeness percentage of $88.80 \%$, and this percentage value has increased compared to before the improvement was made $(+11.80)$. The increase in student achievement was caused by an increase in activities, teacher and student interactions in the learning process in the classroom by applying the Think Pair Share (TPS) Cooperative learning model carried 
out was in line with the teacher's performance values. Thus, the success criteria have been achieved successfully in cycle II.

Keywords: learning achievement; Think Pair Share (TPS) type of cooperative learning

\section{PENDAHULUAN}

Mencapai prestasi belajar yang tinggi menjadi cita-cita bukan hanya siswa tetapi juga guru. Dalam konteks pembelajaran Bahasa Indonesia di SMA prestasi tinggi tersebut adalah siswa mampu memproduksi dan menggunakan teks sesuai dengan tujuan dan fungsi sosialnya. Bahasa Indonesia diajarkan bukan sekadar sebagai pengetahuan bahasa, melainkan sebagai teks yang mengemban fungsi untuk menjadi sumber aktualisasi diri penggunanya pada konteks sosial-budaya akademik. Untuk mencapai prestasi yang tinggi tentu melewati proses belajar, bukan sekedar belajar akan tetapi belajar dengan tepat dan efektif.

Menurut de Porter dan Hernacki (2001), belajar adalah kombinasi dari bagaimana menyerap, lalu mengatur dan mengolah informasi (bahan ajar). Ada tiga bentuk modalitas belajar yaitu visual, auditorial dan kinestik dan empat dominasi otak yaitu sequensional abstrak. Belajar itu senantiasa merupakan perubahan (change) tingkah laku (behavior) atau penampilan, dengan serangkaian kegiatan seperti membaca, mengamati, mendengarkan, meniru, dan lain sebagainya. Dalam pengertian luas, belajar dapat diartikan sebagai kegiatan psiko fisik menuju perkembangan pribadi seutuhnya, dalam arti sempit belajar dimaksudkan sebagai usaha penguasaan materi ilmu pengetahuan yang merupakan sebagian kegiatan menuju terbentuknya kepribadian seutuhnya.

Pembelajaran yang efektif diperlukan model pembelajaran yang tepat. Berbagai model pembelajaran ditawarkan dengan berbagai tipe dalam dunia pendidikan. Berdasarkan pembelajaran pra-siklus, sebelum pelaksanaan penelitian yang dilakukan oleh peneliti pada saat proses pembelajaran kelas XI MIPA 1 SMAN 2 Bolo ditemukan bahwa terdapat banyak peserta didik yang setelah belajar Bahasa Indonesia tidak mampu mewujudkan tujuan ideal pembelajaran Bahasa Indonesia yakni siswa mampu memproduksi dan menggunakan teks sesuai dengan tujuan dan fungsi sosialnya, bahasa Indonesia diajarkan bukan sekadar sebagai pengetahuan bahasa.

Dari hasil refleksi dan keterangan siswa tentang pembelajaran Bahasa Indonesia menulis teks resensi kelas XI MIPA 1 khususnya pada materi menulis teks resensi, siswa-siswa tersebut kurang memahami tentang materi menulis teks resensi dan maupun menulis teks resensi. Motivasi dan minat belajar siswa dalam diri rendah, hal ini disebabkan karena cara mengajar guru, peneliti belum optimal, belum sesuai dengan kebutuhan siswa. Selain itu, selama ini proses pembelajaran Bahasa Indonesia di kelas tersebut kebanyakan masih mengunakan mind set yang konvensional dimana guru memberikan pengetahuan kepada siswa yang pasif. Guru kurang menguasai metode-metode efektif yang sesuai dengan Kurikulum 2013, proses pembelajaran masih tertuju pada aspek kognitif, sedangkan tujuan aspek psikomotorik, keterampilan masih sangat kurang mendapatkan perhatian. Guru mengajar dengan metode konvensional yaitu metode ceramah dan mengharapkan siswa duduk, diam, dengar, catat dan hafal, sehingga kegiatan pembelajaran menjadi monoton dan kurang menarik perhatian siswa, tidak memugkinkan siswa beraktivitas dan berinteraksi secara optimal dengan sumber belajar dan teman-teman sekelas. 
Kondisi seperti terjadi selama pembelajaran pra-siklus dan berdampak pada rendahnya motivasi dan aktivitas belajar siswa dalam memahami pembelajaran Bahasa Indonesia. Akibatnya nilai akhir yang dicapai siswa rendah dan tidak seperti yang diharapkan, demikian pula dengan kinerja guru juga rendah. Indikator rendahnya prestasi belajar siswa dan kinerja guru ditunjukkan dengan tidak tercapainya indikator kinerja guru yang ditetapkan. Prestasi belajar siswa ditetapkan rata-rata menyesuaikan $\mathrm{KKM}$ yakni rata-rata $\geq 70.00$ dengan ketuntasan klasikal $72.00 \%$.

Pembelajaran kooperatif tipe Think Pair Share (TPS) dijadikan alternatif solusi perbaikan karena memiliki kelebihan dan fleksibilitas dalam "waktu berfikir atau waktu tunggu" yang disediakan dalam pembelajaran tipe ini, dan cocok untuk mengatasi masalah menemukan solusi atas permasalahan pebelajaran pra-siklus pada pembelajaran Bahasa Indonesia kelas XI MIPA 1 materi menulis teks resensi. Model pembelajaran ini juga sesuai dengan Kurikulum 2013.

\section{KAJIAN TEORI (opsional)}

\section{Pembelajaran Bahasa Indonesia dalam Kurikulum 2013}

Pada Kurikulum 2013, pengembangan kurikulum mata pelajaran Bahasa Indonesia menggunakan pendekatan pembelajaran bahasa berbasis teks. Pada pendekatan ini diharapkan siswa mampu memproduksi dan menggunakan teks sesuai dengan tujuan dan fungsi sosialnya, bahasa Indonesia diajarkan bukan sekadar sebagai pengetahuan bahasa, melainkan sebagai teks yang mengemban fungsi untuk menjadi sumber aktualisasi diri penggunanya pada konteks sosial-budaya akademik. Teks dimaknai sebagai satuan bahasa, baik verbal maupun nonverbal, yang mengungkapkan makna secara kontekstual.

Teks adalah satuan bahasa yang mengandung makna, pikiran, dan gagasan yang lengkap secara kontekstual. Teks tidak selalu berwujud bahasa tulis, sebagaimana lazim dipahami, soalnya teks Pancasila yang sering dibacakan pada saat upacara. Teks dapat berwujud baik tulis maupun lisan, bahkan dalam multimoda, teks dapat berwujud perpaduan antara teks lisan atau tulis dan gambar/animasi/film.

Teks itu sendiri memiliki dua unsur utama, yaitu konteks situasi dan konteks budaya. Konteks situasi berkenaan dengan penggunaan bahasa yang di dalamnya terdapat register yang melatarbelakangi lahirnya teks, yaitu adanya sesuatu (pesan, pikiran, gagasan, ide) yang hendak disampaikan (field); sasaran atau partisipan yang dituju oleh pesan, pikiran, gagasan, atau ide itu (tenor); dan format bahasa yang digunakan untuk menyampaikan atau mengemas pesan, pikiran, gagasan, atau ide itu (mode). Terkait dengan format bahasa tersebut, teks dapat diungkapkan ke dalam berbagai jenis, soalnya deskripsi, laporan, prosedur, eksplanasi, eskposisi, diskusi, naratif, cerita petualangan, anekdot, dan lain-lain.

Konteks yang kedua adalah konteks situasi dan konteks budaya masyarakat tutur bahasa yang menjadi tempat jenis-jenis teks tersebut diproduksi. Konteks situasi merupakan konteks yang terdekat yang menyertai penciptaan teks, sedangkan konteks sosial atau konteks budaya lebih bersifat institusional dan global.

Struktur teks membentuk struktur berpikir, sehingga di setiap penguasaan jenis teks tertentu, siswa akan memiliki kemampuan berpikir sesuai dengan struktur teks yang dikuasainya. Dengan berbagai macam teks yang dikuasainya, siswa akan mampu menguasai berbagai struktur berpikir. Bahkan, satu topik tertentu dapat 
disajikan ke dalam jenis teks yang berbeda dan tentunya dengan struktur berpikir yang berbeda pula. Hanya dengan cara itu, siswa kemudian dapat mengonstruksi ilmu pengetahuannya melalui kemampuan mengobservasi, mempertanyakan, mengasosiasikan, menganalisis, dan menyajikan hasil analisis secara memadai.

Selain itu, secara garis besar teks dapat dipilah atas teks sastra dan teks nonsastra. Teks sastra dikelompokkan ke dalam teks naratif dan nonnaratif. Adapun teks nonsastra dikelompokkan ke dalam teks jenis faktual yang di dalamnya terdapat subkelompok teks laporan dan prosedur dan teks tanggapan yang dikelompokkan ke dalam subkelompok teks transaksi dan eksposisi. Dengan memperhatikan jenis-jenis teks di atas, termasuk unsur utama yang harus ada di dalam teks, melalui pembelajaran bahasa berbasis teks, materi sastra dan materi kebahasan dapat disajikan.

\section{Metode Pembelajaran Bahasa Indonesia}

Metode pembelajaran bahasa Indonesia pada jenjang SMP, SMA, dan SMK terdiri atas empat tahap, yaitu:

\section{a. Membangun Konteks}

Tahapan pertama dalam pembelajaran berbasis teks dimulai dari memperkenalkan konteks sosial dari teks yang dipelajari. Kemudian mengeksplorasi ciri-ciri dari konteks budaya umum dari teks yang dipelajari serta mempelajari tujuan dari teks tersebut. Selanjutnya adalah dengan mengamati konteks dan situasi yang digunakan. Soalnya dalam teks eksposisi, siswa harus bisa memahami peran dan hubungan antara orang-orang yang berdialog apakah antar teman, editor dengan pembaca, guru dengan siswa, dan sebagainya. Siswa juga harus memahami media yang digunakan apakah percakapan tatap muka langsung atau percakapan melalui telepon.

Membangun konteks melalui kegiatan mengamati teks dalam konteksnya dan menanya tentang berbagai hal yang berkaitan dengan teks yang diamatinya. Pada langkah membangun konteks siswa dapat didorong untuk memahami nilai spiritual, nilai budaya, tujuan yang melatari bangun teks. Pada proses ini siswa mengeksplorasi kandungan teks serta nilai-nilai yang tersirat di dalamnya. Di sini siswa dapat mengungkap laporan hasil pengamatan untuk bahan tindak lanjut dalam kegiatan belajar.

Kegiatan yang dapat dilakukan di dalam kelas adalah: (a) mempresentasikan konteks. Untuk menyajikan suatu konteks, bisa menggunakan berbagai media antara lain melalui gambar, benda nyata, field-trip, kunjungan, wawancara kepada narasumber dan sebagainya, (b) membangun tujuan sosial. Untuk mengetahui tujuan sosial bisa melalui diskusi, survey, dan yang lainnya, (c) membandingkan dua kebudayaan. Membandingkan penggunaan teks antara dua kebudayaan berbeda, yaitu kebudayaan kita dengan kebudayaan penutur asli, (d) Membandingkan model teks dengan teks yang lainnya. Contohnya membandingkan percakapan antara teman dekat, teman kerja, atau orang asing.

\section{b. Pemodelan}

Pada tahap ini, siswa mengamati pola dan ciri-ciri dari teks yang diajarkan. Siswa dilatih untuk memahami struktur dan ciri-ciri kebahasaan teks. Pada langkah ini siswa didorong untuk meningkatkan rasa ingin tahu dengan memperhatikan 1) simbol, 2) bunyi 3) tata bahasa, dan 4) makna. Melalui analisis fakta dan data pada teks yang dipelajarinya siswa memperoleh model imbuhan, struktur imkata, frase, 
klausa, kalimat, maupun paragraf. Semua hal tersebut siswa pelajari pada konteks pemakaiannya. Pada tahapan ini siswa dapat mengeksplorasi jenis teks yang dipelajarinya serta mengenali ciri-cirinya. Proses aktivitas pengenalan bukan sebagai tujuan akhir pembelajaran, melainkan sebagai awal kegiatan untuk mengembangkan daya cipta.

Pada tahap pemodelan, guru dapat mengenalkan nilai, tujuan sosial, struktur, ciri-ciri bentuk, serta ciri kebahasaaan yang menjadi penanda teks yang diajarkan. Kegiatan yang siswa lakukan pada tahap ini adalah siswa diminta membaca teks, tanya jawab tentang makna teks, melabeli teks, diskusi kelompok.

c. Menyusun Teks Secara Bersama

Dalam tahapan ini, siswa mulai memahami keseluruhan teks. Guru secara perlahan mulai mengarahkan siswa agar mandiri sehingga siswa menguasai model teks yang diajarkan. Kegiatan yang dapat dilakukan di dalam kelas antara lain mendiskusikan jenis teks, melengkapi teks rumpang, membuat kerangka teks, melakukan penilaian sendiri atau penilaian antar teman sebaya, dan bermain tekateki. Siswa menggunakan hasil mengeksplorasi model-model teks untuk membangun teks dengan cara berkolaborasi dalam kelompok. Melalui kegiatan ini diharapkan semua siswa dapat memperoleh pengalaman mencipta teks sebagai dasar untuk mengembangkan kompetensi individu.

\section{d. Menyusun Teks Secara Mandiri}

Setelah melalui tahapan kesatu sampai tahapan ketiga, siswa telah memiliki pengetahuan mengenai model teks yang diajarkan. Siswa mulai memiliki kemampuan yang cukup untuk menulis teks yang mirip dengan model teks yang diajarkan. Dalam tahapan ini, siswa mulai mandiri dalam mengerjakan teks dan peran guru hanya mengamati siswa untuk penilaian.Kegiatan yang dapat dilakukan dalam tahapan ini antara lain (a) Untuk meningkatkan kemampuan mendengarkan, siswa merespon teks lisan, menggaris bawahi teks, menjawab pertanyaan, dan lainlain, (b) Untuk meningkatkan kemampuan mendengarkan dan berbicara, siswa bermain peran, melakukan dialog berpasangan atau berkelompok, (c) Untuk meningkatkan kemampuan berbicara, siswa melakukan presentasi di depan kelas, (d) Untuk meningkatkan kemampuan membaca, siswa merespon teks tertulis, menggaris bawahi teks, menjawab pertanyaan, dan lain-lain, (e) Untuk meningkatkan kemampuan menulis, siswa membuat draft dan menulis teks secara keseluruhan.

\section{Belajar dan Prestasi Belajar}

Pengertian dari beberapa ahli tentang belajar diantaranya dari Winkel (1991) Belajar adalah suatu aktivitas mental/psikis yang berlangsung dalam interaktif aktif dengan lingkungan, yang menghasilkan perubahan-perubahan dalam pengetahuan pemahaman, ketrampilan dan nilai sikap.

Menurut Suryabrata (1980) Belajar adalah rangkaian suatu aktivitas yang dilakukan seseorang dan mengakibatkan perubahan dalam dirinya berupa perubahan pengetahuan atau kemahiran yang sifatnya permanent.

Sedangkan menurut Ngalim (1990) belajar adalah setiap perubahan yang relative menetap dalam tingkah laku yang terjadi sebagai suatu hasil latihan atau pengalaman.

Belajar adalah perubahan tingkah laku yang merupakan hasil dari pengalaman dan latihan. Prestasi belajar adalah informasi tentang pengetahuan, sikap perilaku 
serta ketrampilan yang dicapai oleh siswa setelah berpartisipasii dalam kegiatan pembelajarn selama rentang waktu tertentu.

Menurut de Porter dan Hernacki (2001) belajar adalah kombinasi dari bagaimana menyerap, lalu mengatur dan mengolah informasi (bahan ajar). Ada tiga bentuk modalitas belajar yaitu visual, auditorial dan kinestik dan empat dominasi otak yaitu sequensional abstrak. Belajar itu senantiasa merupakan perubahan (change) tingkah laku (behavior) atau penampilan, dengan serangkaian kegiatan seperti membaca, mengamati, mendengarkan, meniru, dan lain sebagainya. Dalam pengertian luas, belajar dapat diartikan sebagai kegiatan psiko fisik menuju perkembangan pribadi seutuhnya, dalam arti sempit belajar dimaksudkan sebagai usaha penguasaan materi ilmu pengetahuan yang merupakan sebagian kegiatan menuju terbentuknya kepribadian seutuhnya.

Dari berbagai pendapat tersebut diatas kiranya dapat disimpulkan bahwa prestasi belajar adalah hasil atau perolehan seseorang berupa pengusaan pengetahuan, ketrampilan, maupun sikap. Secara nyata prestasi belajar bisa berupa nilai tes, nilai rapor, nilai UN, nilai ijazah. Dalam konteks ini yang dimaksud dengan prestasi belajar adalah nilai pos tes.

Prestasi belajar yang dicapai oleh siswa di sekolah merupakan salah satu ukuran terhadap penguasaan materi pelajaran yang disampaikan. Peran guru dalam menyampaikan materi pelajaran dapat mempengaruhi hasil belajar siswa. Faktorfaktor yang mempengaruhi prestasi belajar siswa penting sekali untuk diketahui, artinya dalam rangka membantu siswa mencapai prestasi belajar yang seoptimal mungkin.

\section{Think Pair Share (TPS) Type of Cooperative Learning}

\section{a. Think Pair Share (TPS)}

Menurut Cholis (2006) Think Pair Share adalah suatu metode pembelajaran kooperatif yang memberi siswa waktu untuk berfikir dan merespon serta saling bantu satu sama lain. Metode ini memperkenalkan ide "waktu berfikir atau waktu tunggu" yang menjadi faktor kuat dalam meningkatkan kemampuan siswa dalam merespon pertanyaan. Pembelajaran Kooperatif model Think-Pair-Share ini relatif lebih sederhana karena tidak menyita waktu yang lama untuk mangatur tempat duduk ataupun mengelompokkan siswa. Pembelajaran ini melatih siswa untuk berani berpendapat dan menghargai pendapat teman.

Pembelajaran Think-Pair-Share (TPS) memiliki prosedur yang ditetapkan secara implisit untuk memberi siswa waktu lebih banyak untuk berpikir, menjawab permasalahan dan saling membantu satu sama lain. Prosedur tersebut telah disusun dan dibentuk sedemikian rupa sehingga dapat memberikan waktu yang lebih banyak kepada siswa untuk dapat berpikir dan merespon yang nantinya akan membangkitkan motivasi siswa.

Teknik ini memberi siswa kesempatan untuk bekerja sendiri serta bekerja sama dengan orang lain. Menggunakan metode klasikal yang memungkinkan hanya satu siswa maju dan membagikan hasilnya untuk seluruh kelas, teknik think-pairshare ini memberi kesempatan sedikitnya delapan kali lebih banyak kepada siswa untuk dikenali dan menunjukkan partisipasi mereka kepada orang lain, yaitu pada saat guru mempresentasikan sebuah pelajaran di kelas, siswa duduk berpasangan di dalam tim mereka. 
Melalui cara seperti ini diharapkan siswa mampu bekerja sama, saling membutuhkan dan saling bergantung pada kelompok-kelompok kecil secara koooperatif. Pembelajaran dengan think pare ini akan memberikan variasi tersendiri dalam lingkungan belajar siswa. Silberman (2002) dalam bukunya mengemukakan bahwa salah satu cara terbaik untuk mengembangkan belajar yang aktif adalah memberikan tugas belajar yang diselesaikan dalam kelompok kecil siswa. Dengan menggunakan metode Think Pair Share siswa belajar dari satu sama lain dan berupaya bertukar ide dalam kelompoknya. Rasa percaya diri siswa meningkat dan semua siswa mempunyai kesempatan berpartisipasi di kelas karena sudah memikirkan jawaban atas pertanyaan guru, tidak seperti biasanya hanya siswa siswa tertentu saja yang menjawab.

b. Langkah-Langkah PembelajaranThink Pair Share (TPS)

Model pembelajaran think pair share ini merupakan model pembelajaran yang dilakukan untuk meningkatkan belajar kolaboratif dan mendorong kepentingan dan keuntungan sinergi itu. Langkah- langkah dalam Pembelajaran Kooperatif Tipe Think Pair Share (TPS) sebagai berikut: 1) Berfikir (thinking); dimana guru mengajukan suatu pertanyaan atau masalah yang dikaitkan dengan pelajaran, dan meminta siswa menggunakan waktu beberapa menit untuk berfikir sendiri jawaban atau masalah, 2) Berpasangan(pairing), saat siswa berpasangan, mendiskusikan apa yang mereka peroleh dalam langkah sebelumnya dan interaksi selama waktu yang disediakan dapat menyatukan gagasan masing- masing siswa, 3) Berbagi(sharing), sebagai tahap akhir, dimana guru meminta pasangan-pasangan untuk berbagi dengan kelompok berpasangan keseluruhan kelas, dan kegiatan sharing ini dilanjutkan sampai sekitar sebagian pasangan mendapat hasil dari yang didiskusikan untuk dilaporkan atau dipresentasikan.

c. Kelebihan dan Kekurangan PembelajaranThink Pair Share (TPS)

Menurut Lie (2004), kelebihan tipe TPS adalah sebagai berikut: 1) memungkinkan siswa untuk merumuskan dan mengajukan pertanyaan-pertanyaan mengenai materi yang diajarkan karena secara tidak langsung memperoleh contoh pertanyaan yang diajukan oleh guru, serta memperoleh kesempatan untuk memikirkan materi yang diajarkan, 2) Siswa akan terlatih menerapkan konsep karena bertukar pendapat dan pemikiran dengan temannya untuk mendapatkan kesepakatan dalam memecahkan masalah, 3) Siswa lebih aktif dalam pembelajaran karena menyelesaikan tugasnya dalam kelompok, dimana tiap kelompok hanya terdiri dari 2 orang, 4) Siswa memperoleh kesempatan untuk mempersentasikan hasil diskusinya dengan seluruh siswa sehingga ide yang ada menyebar, dan 5) Memungkinkan guru untuk lebih banyak memantau siswa dalam proses pembelajaran.

Sedangkan menurut Huda (2013) menyatakan kelebihan/ manfaat tipe TPS antara lain a) memungkinkan siswa untuk bekerja sendiri dan bekerja sama dengan orang lain, b) mengoptimalkan partisipasi siswa, dan c) memberikan kesempatan kepada siswa untuk menunjukkan partisipasi mereka kepada orang lain.

Sedangkan kekurangan dalam pelaksanan tipe TPS ini antara lain adalah : (a) banyak kelompok yang melaporkan dan perlu dimonitor, (b) lebih sedikit ide yang muncul, dan (c) jika ada perselisihan, tidak ada penengah. Selanjutnya menurut Fadholi (2009), ada 5 kelemahan tipe TPS, sebagai berikut: a) Jumlah murid yang ganjil berdampak pada saat pembentukan kelompok, karena ada satu murid tidak mempunyai pasangan; b) Jika ada perselisihan,tidak ada penengah; c) Jumlah 
kelompok yang terbentuk banyak; d) Menggantungkan pada pasangan; e) Sangat sulit diterapkan di sekolah yang rata-rata kemampuan muridnya rendah.

\section{METODE PENELITIAN}

Penelitian tindakan perbaikan pembelajaran dilakukan pada siswa-siswi kelas XI MIPA 1 SMAN 2 Bolo dengan jumlah siswa 32 terdiri dari 15 orang laki-laki dan 17 orang perempuan. Penelitian tindakan kelas dilakukan dalam 4 fase yaitu: perencanaan (planning), tindakan (action), pengamatan (observation), dan refleksi (reflection) dalam meneliti faktor prestasi belajar, ketuntasan belajar dan kinerja guru dalam penerapan TPS dalam pembelajaran Bahasa Indonesia materi menulis teks resensi. Selanjutnya data yang dibutuhkan diperoleh melalui instrumen perbaikan berupa performance test dan lembar observasi kinerja guru.

Sebagai target yang ingin dicapai, kriteria keberhasilan penelitian ditetapkan sebagai berikut: 1) prestasi belajar siswa, rata-rata nilai post test untuk pada Pelajaran Bahasa Indonesia diharapkan mencapai $\geq 73,2$ ) prosentase ketuntasan belajar siswa mencapai $\geq 85 \%$, dan 3 ) kinerja guru, mencapai $\geq 92.50$ untuk perencanaan dan $\geq 93.30$ untuk pelaksanaan.

\section{HASIL DAN PEMBAHASAN}

\section{A. Siklus 1}

Pada perencanaan model pembelajaran Think Pair Share (TPS), guru dan rekan sejawat menyusun rencana perbaikan pembelajaran (RPP) yang diintegrasikan dengan 3 langkah utama dalam TPS, yaitu: berpikir (Think), berpasangan (Pair), dan berbagi (Share). Langkah-langkah penting ini diberikan waktu tunggu yang sesuai untuk memberikan peluang ide tersampaikan dengan baik.

Secara keseluruhan pelaksanaan pembelajaran dengan penerapan model pembelajaran kooperatif tipe Think Pair Share (TPS) telah berjalan dengan baik. Akan tetapi, hasil post test sebagai prestasi belajar siklus I tidak mencapai kriteria keberhasilan yang ditetapkan, seperti yang bisa diamati pada Tabel 1.

Tabel 1. Prestasi Belajar Siswa pada Siklus I

\begin{tabular}{ccc}
\hline & Pra siklus & Siklus I \\
\hline Rata-rata Nilai & 70.00 & 72.70 \\
\hline \% Ketuntasan Klasikal & 72.00 & 77.00 \\
\hline
\end{tabular}

Hasil post test menunjukkan bahwa prestasi belajar siswa siklus I rata-rata 72.70 nilai rata-rata ini mengalami peningkatan sebelum diadakan perbaikan $(+2.70)$ dengan persentase ketuntasan $77.00 \%$, nilai persentase ini mengalami peningkatan dibanding sebelum diadakan perbaikan $(+5.00)$. Meskipun nilai ini mengalami peningkatan tetapi dari sisi prestasi belajar siklus I belum mencapai indikator yang ditetapkan yakni rata-rata $\geq 73.00$, porsentase ketuntasan $\geq 85.00 \%$.

Pada Tabel 2 dapat diamati skor nilai kinerja guru, dimana keberhasilan perencanaan pembelajaran untuk siklus I mencapai 91.85\%. Nilai kinerja ini mengalami peningkatan dibandingkan sebelum diadakan perbaikan $(+0.85)$. Sementara itu, keberhasilan pelaksanaan pembelajaran siklus I mencapai $92.45 \%$. Meskipun nilai kinerja guru ini mengalami peningkatan sebelum diadakan perbaikan 
$(+0.45)$, tetapi dari segi kinerja guru siklus I ini belum mencapai indikator yang ditetapkan yakni untuk perencanaan adalah $\geq 92.50 \%$ dan untuk pelaksanaan pembelajaran adalah $\geq 93.30 \%$.

Tabel 2. Kinerja Guru pada Siklus I

\begin{tabular}{ccc}
\hline & Pra siklus & Siklus I \\
\hline \% Keberhasilan Perencanaan & 91.00 & 91.85 \\
\hline \% Keberhasilan Pelaksanaan & 92.00 & 92.45 \\
\hline
\end{tabular}

Faktor utama yang menyebabkan belum tercapainya indikator prestasai belajar dan kinerja guru disebabkan guru belum mampu melaksanakan seluruh langkahlangkah kunci secara optimal. Menurut hasil pengamatan observer, langkah-langkah yang perlu diperbaiki, antara lain:

1. Pada kegiatan inti langkah berpikir (Think)

Terdapat beberapa siswa yang pasif yang tidak dapat menyusun, mengajukan pertanyaan. Beberapa siswa yang lain hanya dapat mengajukan satu pertanyaan dari salaah satu dari 3 aspek yang dibahas. Sementra terdapat siswa-siswa yang dengan cepat dan tepat mengajukan 3 aspek yang dibahas.

Dalam hal ini guru terfokus pada siswa-siswa yang dengan tepat menyusun pertanyaan. Guru perlu melakukan monitoring secara merata khususnya pada siswasiswa yang terkendala, kesulitan dalam menyusun pertanyaan, sehingga seluruh siswa dapat mengerjakan langkah-langkah yang diharapkan dengan baik.

2. Pada kegiatan inti langkah berpasangan (Pair)

Pada langkah ini, beberapa pasangan siswa tidak dapat menentukan ciri kebahasaan teks resensi dan menyimpulkan isi pokok teks resensi dikarenakan dalam penentuan pasangan berdasarkan tempat duduk terdekat, sehingga terdapat beberapa kelompok yang anggotanya sama-sama berkemampuan rendah. Demikian pula ada kelompok yang cepat mengerjakan dengan tepat karena pasangannya sama-sama berkemampuan tinggi. Sehingga terjadi kesenjangan pasangan dalam menyelesaikan tugas.

Guru seharusnya dari awal memperimbangakan pasangan sehingga terjadi pemerataan kemampuan pasangan. Dalam hal ini guru perlu memetakan intake siswa demikian juga perlu memetakan pasangan yang akan dibentuk dalam upaya menunjang keberhasilan pelaksanaan langkah ke-2, yakni Pair (bekerja berpasangan). Selain itu guru perlu memberikan bantuan lebih intensif kepada kelompok yang mengaami hambatan dalam menjalankan tugasnya.

3. Pada langkah mengonstruksi mandiri

Beberapa siswa yang tidak dapat merevisi teksnya dengan baik, dan tidak mau bertanya kepada siswa yang lain pada langkah sebelumnya. Sehingga pada akhir kegiatan inti, draft yang dimasukkan berupa draft yang belum direvisi.

Guru perlu memonitor hasil akhir draft yang disusun siswa sehingga dipastkan draft tersebut bukan asal-asalan melainkan mengikuti rambu-rambu penulisan draft teks resensi yang tepat. Guru dapat memanfaatkan siswa yang kemampuannya tinggi untuk membimbing siswa yang kesulitan menulis draft.

Hasil refleksi menunjukkan bahwa kriteria keberhasilan belum tercapai, sehingga peneliti perlu melanjutkan penelitian ke siklus II. 


\section{B. Siklus II}

Selanjutnya, siklus II direncanakan dan dilaksanakan dengan memodifikasi RPP sebelumnya dengan memperhatikan refleksi pada siklus I. Hasil post test siklus II menunjukkan peningkatan yang signifikan ditunjukkan dalam Tabel 3.

Tabel 3. Prestasi Belajar Siswa pada Siklus II

\begin{tabular}{cccc}
\hline & Pra siklus & Siklus I & Siklus II \\
\hline Rata-rata Nilai & 70.00 & 72.70 & 76.76 \\
\hline \% Ketuntasan Klasikal & 72.00 & 77.00 & 88.80 \\
\hline
\end{tabular}

Hasil post test menunjukkan bahwa prestasi belajar siswa siklus II rata-rata 76.76 nilai rata-rata ini mengalami peningkatan sebelum diadakan perbaikan $(+4.06)$ dengan persentase ketuntasan $88.80 \%$, nilai persentase ini mengalami peningkatan dibanding sebelum diadakan perbaikan (+11.80). Dengan demikian pada siklus II ini telah berhasil mencapai indikator yang ditetapkan yakni rata-rata $\geq 73.00$, porsentase ketuntasan $\geq 85.00 \%$.

Seluruh langkah yang harus diperbaiki telah dilaksanakan dengan baik dengan rincian pelaksanaan pembelajaran perbaikan sebagai berikut:

1. Pada kegiatan inti langkah berpikir (Think)

Seluruh siswa yang pasif pada siklus I dapat menyusun, mengajukan pertanyaan. Dalam hal ini guru tidak lagi terfokus pada siswa-siswa yang dengan tepat menyusun pertanyaan tetapi lebih intensif melakukan monitoring secara merata khususnya pada siswa-siswa yang terkendala, kesulitan dalam menyusun pertanyaan, sehingga seluruh siswa dapat mengerjakan langkah ini dengan baik.

2. Pada kegiatan inti langkah berpasangan (Pair)

Pada langkah ini, seluruh pasangan siswa dapat menentukan ciri kebahasaan teks resensi dan menyimpulkan isi pokok teks resensi. Dalam penentuan pasangan berdasarkan telah melakukan pemetaan intake.

Guru dari awal telah memperimbangakan pasangan sehingga terjadi pemerataan kemampuan pasangan. Dalam hal ini guru telah memetakan intake siswa demikian juga memetakan pasangan yang akan dibentuk dalam upaya menunjang keberhasilan pelaksanaan langkah ke-2, yakni Pair (bekerja berpasangan). Selain itu guru telah secara inttensif memberikan bantuan lebih intensif kepada kelompok yang mengaami hambatan dalam menjalankan tugasnya.

\section{Pada langkah mengonstruksi mandiri}

Seluruh siswa dapat merevisi teksnya dengan baik, pada akhir kegiatan inti, draft yang dimasukkan berupa draft yang telah direvisi.

Guru berhasil memonitor hasil akhir draft yang disusun siswa sehingga dipastkan draft tersebut bukan asal-asalan melainkan mengikuti rambu-rambu penulisan draft teks resensi yang tepat. Guru juga telah memanfaatkan siswa yang kemampuannya tinggi untuk membimbing siswa yang kesulitan menulis draft.

Selanjutnya pada Tabel 4, hasil pengamatan menunjukkan kinerja guru pada siklus II, dimana kinerja guru juga mengalami peningkatan yang signifikan.

Tabel 2. Kinerja Guru pada Siklus I

\begin{tabular}{cccc}
\hline & Pra siklus & Siklus I & Siklus II \\
\hline \% Keberhasilan Perencanaan & 91.00 & 91.85 & 93.00 \\
\hline \% Keberhasilan Pelaksanaan & 92.00 & 92.45 & 94.00 \\
\hline
\end{tabular}


Pada nilai pengamatan kinerja guru, prosentase keberhasilan perencanaan pembelajaran untuk siklus II mencapai 93.00. Nilai kinerja ini mengalami peningkatan dibandingkan sebelum diadakan perbaikan $(+1.15)$. Dan, prosentase keberhasilan pelaksanaan pembelajaran untuk siklus II berada di nilai 94.00. Nilai kinerja guru ini mengalami peningkatan sebelum diadakan perbaikan $(+1.55)$. Dengan perbaikan proses pembelajaran, penelitian pada siklus II berhasil memenuhi indikator yang ditetapkan yakni $\geq 92.50$ untuk perencanaan dan $\geq 93.30$ untuk pelaksanaan pembelajaran.

Sampai siklus II kelebihan-kelebihan model pembelajaran kooperatif tipe Think Pair Share (TPS) telah berhasil dimunculkan, antara lain: 1) memungkinkan siswa untuk merumuskan dan mengajukan pertanyaan-pertanyaan mengenai materi yang diajarkan karena secara tidak langsung memperoleh contoh pertanyaan yang diajukan oleh guru, serta memperoleh kesempatan untuk memikirkan materi yang diajarkan, 2) siswa akan terlatih menerapkan konsep karena bertukar pendapat dan pemikiran dengan temannya untuk mendapatkan kesepakatan dalam memecahkan masalah, 3) siswa lebih aktif dalam pembelajaran karena menyelesaikan tugasnya dalam kelompok, dimana tiap kelompok hanya terdiri dari 2 orang, 4) siswa memperoleh kesempatan untuk mempersentasikan hasil diskusinya dengan seluruh siswa sehingga ide yang ada menyebar, dan 5) memungkinkan guru untuk lebih banyak memantau siswa dalam proses pembelajaran.

Dengan keberhasilan penerapan model pembelajaran kooperatif tipe Think Pair Share (TPS) sampai siklus II ini menunjukkan bahwa hasil refleksi dan kajian referensi dapat diterapkan dengan baik dan berhasil, sehingga tidak perlu dilanjutkan lagi pada siklus berikutnya.

\section{KESIMPULAN}

Hasil penelitian tindakan dalam 2 siklus menunjukkan bahwa penerapan model pembelajaran kooperatif tipe Think Pair Share (TPS) dapat meningkatkan prestasi belajar siswa dan juga meningkatkan kinerja guru pada pembelajaran Bahasa Indonesia pada materi menulis teks resensi di kelas XI MIPA 1 SMAN 2 Bolo Tahun Pelajaran 2020/2021.

\section{DAFTAR PUSTAKA}

Arif Fadholi Wahid Assyafi'i. (2009). Kelebihan Kekurangan TPS. http://ariffadholi.blogspot.co.id/2009/10/kelebihan-kekurangan-tps.html. Diakses 20 Oktober 2015

Asma, Nur. (2006). Model Pembelajaran Kooperatif. Jakarta : Departemen Pendidikan Nasional Direktorat Jenderal Pendidikan tinggi Direktorat Ketenagaan dan Pengembangan.

DePorter, Bobbi \& Mike, Hernacki. (2001). Quantum Learning. Membiasakan Belajar Nyaman dan Menyenangkan. Bandung : Penerbit Kaifa.

Depdiknas. (2001). Kurikulum Berbasis Kompetensi Pelajaran Bahasa Indonesia

Huda, Miftahul. (2011). Cooperative Learning Metode, Teknik, Struktur dan Model Penerapan. Yogyakarta: Pustaka Pelajar. 
Lie, Anita. (2004). Cooperative Learning, Mempraktekkan Cooperative Learning Di Ruang-Ruang Kelas. Jakarta: Grassindo.

Purwanto, Ngalim. (1990). Belajar Berhubungan Dengan Perubahan Tingkah Laku. Jakarta: PT Rineka Cipta.

Sa'dijah, Cholis. (2006). Penerapan Pembelajaran Kooperatif Think Pair Share TPS. Malang: Lembaga Penelitian UM.

Suryabrata, Sumadi. (1980). Psikologi Pendidikan. Jakarta: Rajawali.

Silberma, Muh. (2002). Archieve learning. Yokyakarta: Yapendas.

Winkel, Uzer. (1991). Menjadi Guru Profesional. Bandung: Remaja Rosdakarya. 